\title{
ALASAN DAN TUJUAN LAHIRNYA UNDANG-UNDANG NOMOR 1 TAHUN 1974 TENTANG PERKAWINAN
}

\author{
KHIYAROH \\ UIN Sunan Kalijaga \\ Jl.Marsda Adisucipto Yogyakarta 55281 \\ Khiyaroh5@gmail.com
}

\begin{abstract}
This articles illustrate the process of maked the Marriage Law Number 1 of 1974 begins with government initiatives to discuss the scope of legislative. Government initiatives did not just emerge, but long before they were submitted to the legislative, the government received many inputs regarding marital regulations. Submission of revisions to the marriage regulations were mostly submitted by women's organizations. The process of the formation of the Marriage Law for approximately seven months, starting from the government submitting the Draft Law to the legislature until all factions declare approval article by article. From 77 Articles to 66 Articles to become legislation. But there are many contradictions when the law will be passed. Especially from the Islamic group namely PPP factions they stated that the articles in it violated many Islamic rules. while the faction of the work actually considers its articles to be appropriate. Namely with the article that has highlighted the position of the wife in the household. Another of the PDI factions who only highlighted the issue of polygamy and the principle of monogamy. After being approved and approved by the government the impact of polygamy and divorce decreases. While the problem of Siri marriage is even more widespread.
\end{abstract}

Keyword : Women Organization, Marriage law, Contradiction, Reason, Purpose

\begin{abstract}
Abstrak
Penelitian ini menggambarkan proses dibuatnya Undang-Undang Perkawinan Nomor 1 Tahun 1974 diawali dengan inisiatif pemerintah untuk membahas dilingkup DPR. Inisiatif pemerintah tidak begitu saja muncul tetapi jauh sebelum diajukan di DPR, pemerintah banyak mendapat masukan soal peraturan perkawinan. Pengajuan revisi peraturan perkawinan banyak diajukan oleh
\end{abstract}


organisasi perempuan. Proses terbentuknya Undang-Undang Perkawinan selama kurang lebih tujuh bulan yaitu mulai dari pemerintah menyerahan RUU ke DPR sampai semua fraksi menyatakan peretujuan pasal demi pasal. Dari 77 Pasal menjadi 66 Pasal untuk dijadikan perundang-undangan. Namun banyak pertentangan saat akan disahkanya undang-undang tersebut. Terutama dari golongan islam yaitu fraksi Persatuan pembangunan mereka menyatakan bahwa pasal-pasal didalamnya banyak melanggar aturan Islam. sedangkan fraksi karya justru menganggap pasal-pasalnya sudah sesuai. Yaitu dengan adanya pasal yang sudah menyoroti kedudukan istri dalam rumahtangga. Lain dari fraksi PDI yang hanya menyoroti maslah poligami dan asas monogami. Setelah disetujui dan disahkan oleh pemerintah dampak yang terjadi yaitu poligami dan perceraian berkurang. Sedangkan problem pernikahan siri justru semakin marak.

Kata Kunci : Organisasi Perempuan, Hukum Perkawinan, kontradiksi, Alasan, Tujuan

\section{PENDAHULUAN}

Negara Indonesia merupakan negara yang kaya akan budaya dan keragaman didalamnya. Keragaman tersebut dimulai dari keragam suku bangsa sampai pada keragaman agama yang dianut. Islam, Kristen, Khatolik, Hindu dan Budha merupakan agama yang sudah ada sejak dulu. mereka bebas melaksanakan ajaran agamanya sesuai dengan kepercayaan masing-masing. ${ }^{1}$ Dengan adanya keragaman suku, agama juga pandangan politik membuat terbukanya celah untuk terjadi konflik di Indonesia. Salah satu contoh yaitu saat dilakukan pembahasan mengenai rancangan undang-undang tentang perkawinan. Banyak kalangan yang pro dan kontra terhadap permasalahan rancangan undang-undang perkawinan. Isu dibentuknya rancangan undang-undang perkawinan menjadi permasalahan yang disorot dari berbagai kalangan partai politik dan agama karena perkawinan merupakan hal yang menyeluruh di kalangan masyarakat. Sehingga mereka berusaha menjadikan rancangan undang-undang perkawinan sesuai dengan aturan yang mereka percayai. Pemerintah terutama DPR sebisa mungkin merumuskan pasal-pasal perkawinan yang tidak menyinggung salah satu agama dan tidak menimbulkan problematika lain dikalangan masyarakat. Mengingat pentingnya persatuan yang harus dijaga dan undang-undang tentang perkawinan merupakan aturan yang menyeluruh dikalangan masyarakat.

Gejolak politik maupun agama banyak yang timbul saat proses pembuatan rancangan undang-undang tentang perkawinan. Pertentangan yang paling banyak dilakukan oleh oraganisasi Islam. Organisasi Islam ini melakukan pertentangan

1 Pasal 29 ayat 2 UUD 1945 "Negara menjamin kemerdekaan tiap-tiap penduduk untuk memeluk agamanya masing-masing dan untuk beribadat menurut agamanya dan kepercayaannya itu" 
dengan tujuan membentuk negara berdasarkan asas-asas Islam dan menjadikan pasal-pasal dalam rancangan undang-undang harus sesuai dengan syariat Islam. Hal ini berawal dari kebocoran soal isi rancangan undang-undang perkawinan yang tidak sesuai syariat Islam sudah sampai dikalangan masyarakat padahal rapat pleno anggota DPR mengenai rancangan undang-undang perkawinan belum dilaksanakan. ${ }^{2}$ Sedangkan gejolak politik yang terjadi dikarenakan banyak terjadi pertentang dari berbagai kalangan masyarakat yang mejadikan lamanya proses perumusan rancangan undang-undang perkawinan. Sehingga dari proses perumusan sampai pada pengesahan membutuhkan waktu yang cukup lama, yaitu sekitar tujuh bulan.

Terlepas dari pertentangan-pertentagan mulai dari proses perumusan sampai pengesahan rancangan undang-undang perkawinan, awal mula dirumuskanya rancangan undang-undang perkawinan yaitu karena banyak terjadi permasalahan yang terjadi dalam lingkup keluarga terutama pihak istri yang merasa tidak mempunyai hak dan merasa tertindas dan masih bnyak lagi alasanalasan lain. Hal ini menjadikan banyak organisasi perempuan yang menyuarakan pendapatnya untuk mendapatkan kesetaraan antara laki-laki dan peremuan. Oraganisasi pertama yang mempelopori yaitu Isteri Sedar yang pertama kali didirikan tahun 1930, diketuai oleh Soewarni Djojoseputro seorang aktifis perempuan dalam Jong Java. ${ }^{3}$ Darisinilah dimulai perjuangan masyarakat terutama kaum perempuan menyuarakan hak-hak kesetaraan dan anti poligami. Mereka berusaha mengusulkan kepada pemerintah untuk segera membuat rancangan undang-undang tentang perkawinan. Organisasi-organisasi perempuan berjuang tanpa hentinya dengan tujuan supaya pemerintah segera membuat aturan tentang perkawinan di Indonesia. Berbagai cara dilakukan oleh organisasi-organisasi peremuan, bahkan sampai aksi turun kejalanan dilakukan oleh mereka. Sejarah perjalanan undang-undang perkawinan ini tidaklah sebentar dan mudah. Dengan melihat lagi sejarah perumusan maka akan diketahui apa saja alasan dan tujuan dibentuknya aturan Undang-Undang Nomor 1 Tahun 1974 Tentang Perkawinan.

Tulisan ini bertujuan untuk mengetahui hukum perkawinan yang berlaku di Indonesia sebelum adanya undang-undang perkawinan, apa saja isu-isu yang terjadi sebelum disahkanya undang-undang perkawinan, sejarah lahirnya undangundang perkawinan dan tujuan dibentunya undang-undang perkawinan tahun 1974. Sehingga dalam tulisan ini menggunakan pendekatan sejarah dengan bentuk tulisan kualitatif yang mana mendeskripsikan dari mulai munculnya isu-isu permasalahan dalam perkawinan sampai diundangkanya Undang-Undang Nomor 1 Tahun 1974 Tentang Perkawinan.

\footnotetext{
2 Ahmad Rifai, "Sejarah Undang-Undnag Perkawinan Atas Pendapat Hingga Pertentangan Dari Masyarakat Dan Dewan Perwakilan Rakyat Tahun 1973-1974," Indonesian History, (2015), 1

${ }^{3}$ Cora Vreede-de Stuers, Sejarah Perempuan Indonesia, (Jakarta:Bambu, 2008),286
} 


\section{HASIL DAN PEMBAHASAN \\ HUKUM PERKAWINAN DI INDONESIA}

Aturan hukum tentang perkawinan di Indonesia sudah ada sejak masa sebelum kemerdekaan. Jika diklasifikasikan dapat dikelompokan menjadi tiga yaitu; sebelum merdeka-1946, 1946-1973, dan 1974-sekarang. ${ }^{4}$ Peraturan perkawinan pada masa sebelum kemerdekaan sampai pada tahun 1946 merupakan masa yang menyedihkan. Pada masa ini Indonesia dijajah oleh belanda dengan waktu kurang lebih mendekati 350 tahun. ${ }^{5}$ Dengan adanya penjajahan belanda juga meninggalkan hukum perkawinan untuk orang-orang Indonesia. Pada saat itu hukum perkawinan tertulis peninggalan belanda yang beraku untuk masyarakat Indonesia yaitu Ordonansi perkawinan Kristen (HOCI) berlaku untuk orang Indonesia beragama Kristen. Ditulis di staatsblat 1933 No 73, kitab undangundang hukum perdata (BW) yang digunakan untuk orang Eropa dan keturunan Cina, dan peraturan tentang perkawinan camuran yang diatur dalam staatsblad 1898 N0 158.6 Sampai berakhirnya masa penjajahan pemerintah Belanda tidak berhasil merumuskan hukum perkawinan yang berlaku bagi seluruh masyarakat. Hukum perkawinan untuk orang muslim hanya sebatas hukum materiil yang diambil dari kitab-kitab fikih karangan ulama terdahulu. Hukum perkawinan yang berlaku setelah penjajahan Belanda dapat diklasifikasikan sebagai berikut:

1. Bagi orang-orang Indonesia asli yang bergama islam berlaku hukum agama yang telah diresepsi dengan hukum adat. Bagi orang-orang Indonesia lainya yang beragama selain islam berlaku hukum adat.

2. Orang-orang Indonesia asli yang beragama Kristen berlaku Huwelijks Ordonantie christen Indoneia (HOCI) dalam Staatsblad 1933 No.74

3. Orang-orang timur asing, Eropa dan orang Indonesia keturunan Cina berlaku hukum perdata Burgerlijk Wetboek. ${ }^{7}$

Dari uraian diatas dapat diketahui bahwa hukum yang diterapkan dalam hal perkawinan yang dianut oleh Indonesia masih sangat beragam. Dengan adanya keberagaman hukum dan belum adanya hukum tertulis yang dapat mencakup seluruh masyarakat Indonesia membuat perjalanan penerapan hukum yang mudah untuk dimanipusali.

Satu tahun setelah Indonesia merdeka, tahun 1946 banyak terjadi permasalahan perkawinan pada orang-orang Islam. hal ini disebabkan karena tidak adanya kodifikasi hukum perkawinan untuk orang-orang Islam. orang-orang yang beragama Islam berpedoman pada kitab-kitab fikih seperti kitab Imam Syafii

\footnotetext{
${ }^{4}$ Ahmad Rifai, "Sejarah Undang-Undnag Perkawinan Atas Pendapat Hingga Pertentangan Dari Masyarakat Dan Dewan Perwakilan Rakyat Tahun 1973-1974," Indonesian History, (2015), 2

5 Diakses di https://nasional.kompas.com/read/2018/08/28/15540211/benarkah-indonesiadijajah-belanda-selama-350-tahun?page=all pada Kamis 19 September 2019

6 Taufiqurrahman Syahuri, Legislasi Hukum Perkawinan di Indonesia, (Jakarta: Kencana, 2013), 100

7 Wirjono Prodjodikoro, Hukum Perkawinan di Indonesia, (Jakarta: Sumur Bandung, 1981), 15
} 
misalnya. Karena banyak terjadi perbedaan dalam menerapkan hukum maka timbul permasalahan seperti perkawinan anak, perkawinan paksa, penyalahgunaan hak dan poligami. Kemudian pada tanggal 26 November 1946 pemerintah mulai membuat peraturan yaitu Undang-Undang Nomor 22 Tahun 1946 tentang pencatatan nikah, talak dan rujuk yang diberlakukan di Jawa dan Madura disahkan oleh presiden Soekarno di Linggarjati. Kemudian diberlakukan juga di wilayah Sumatera. ${ }^{8}$ Pelaksanaan undang-undang tersebut diterbitkan Intruksi Menteri Agama Nomor 4 tahun 1974 yang ditujukan untuk pegawai pencatat nikah (PPN).

\section{ISU-ISU PERMASALAHAN DALAM KELUARGA SEBELUM ADANYA UNDANG- UNDANG NOMOR 1 TAHUN 1974 TENTANG PERKAWINAN}

Hukum perkawinan yang berlaku sejak sebelum kemerdekaan sampai era sekarang selalu mengalami perubahan. Sebelum merdeka terdapat beberapa hukum yang digunakan yang sudah dijelaskan diatas. Setelah kemerdekaan dibentuk peraturan Undang-Undang Nomor 22 Tahun 1946 tentang pencatatan nikah, talak dan rujuk yang diberlakukan di Jawa dan Madura. ${ }^{9}$ Munculnya Undang-Undang Nomor 22 Tahun 1946 sebatas mengatur nikah, talak, dan rujuk sehingga hanya mengatur hukum acara. Sedangkan materi hukum yang dijadikan rujukan dalam menyelesaikan perkara untuk orang islam masih bersumber pada kitab-kitab fikih. Sebagai bukti yaitu adanya Statuta Batavia 1642 yang menyebutkan bahwa jika terdapat sengketa waris antara orang pribumi yang beragama Islam maka diselesaikan menggunakan hukum Islam. Selain itu digunakannya kitab Muharrar dan Pepakem Cirebon dan juga beberapa kitab hukum Islam yang digunakan didaerah lain. ${ }^{10}$ Dengan adanya perbedaan sumber yang digunakan tentu akan menghasilkan putusan hukum yang berbeda meskipun dalam kasus yang sama. Selain itu pemahaman umat Islam di Indonesia terhadap kitab-kitab fikih tentu berbeda-beda dan hal ini menimbulkan kasus-kasus baru seperti perkawinan paksa, perkawinan anak dan juga adanya poligami. ${ }^{11}$

Permasalahan-permasalahan keluarga selalu muncul dalam setiap masa. Permasalahan keluarga yang banyak dibahas oleh organisasi perempuan sejak sebelum adanya kemerdekaan yaitu kesewenang-wenangan keluarga. Salah satu contohnya yaitu banyaknya poligami yang dilakukan saat itu. Poligami tidak hanya dilakukan oleh masyarakat dengan garis keturuan matrilineal tetapi juga banyak dilakukan dalam masyarakat dengan sistem patrilinel. Data tersebut dapat dilihat

\footnotetext{
${ }^{8}$ Nani Suwondo, Kedudukan Wanita Indonesia Dalam Hukum Dan Masyarakat, (Jakarta Ghalia Indonesia, 1992), 96

9 Wasman dan Wardah Nuroniyah, Hukum Perkawinan Islam di Indonesia, (Yogyakarta: Teras, 2000), 7

${ }^{10}$ Khoiruddin Nasution, Status Wanita di Asia Tenggara: Studi Terhadap Perundang-undangan Perkawinan Islam Kontemporer di Indonesia dan Malaysia, (Jakarta: INIS, 2002), 39

${ }^{11}$ Wila Chandrawila Supriadi, Hukum Perkawinan Indonesia dan Belanda, (Bandung: Bandar Maju, 2002), 194
} 
dalam Indisc Verlagh tahun 1930. Data menyebutkan jumlah laki-laki yang beristri satu orang sebanyak 11.418 .297 orang (97,5\%) sedangkan yang beroligami berjumlah 302.726 orang $(2,5 \%) .{ }^{12}$ Dengan maraknya poligami tentu permasalahan keluarga semakin rumit dan pihak istri merasa hak-haknya sebagai perempuan tidak dilindungi. Hal ini membuat organisasi perempuan bergerak untuk menentang dan mendesak pemerintah untuk membuat hukum perkawinan yang mengatur hal tersebut.

\section{SEJARAH KELAHIRAN UNDANG-UNDANG NOMOR 1 TAHUN 1974 TENTANG PERKAWINAN}

Peraturan perkawinan dalam Undang-Undang Nomor 1 Tahun 1974 tidak langsung dirumuskan begitu saja. Jauh sebelum dirumuskan undang-undang perkawinan, banyak organisasi perempuan yang konsen dalam permaslahanpermasalahan perkawinan. Pada tahun 1930 berdiri organisasi perempuan yang menentang keras adanya poligami yaitu Isteri Sedar. Menurut Isteri Sedar organisasi Perikatan Perhimpunan Istri Indonesia (PPII) yang dibangun atas dasar kesamaan sosial, agama dan masalah nasional tidak bisa mengatasi masalah poligami, sehingga Isteri Sedar tidak menggabungkan diri dengan PPII. ${ }^{13}$ Pendapat Isteri Sedar dalam menentang poligami mendapatkan kecaman dari organisasi perempuan Islam. Tahun 1932 organisasi Aisyiah meyatakan bahwa kedudukan perempuan dalam Islam dan poligami diperbolehkan dan sah dalam Islam. ${ }^{14}$ Tahun 1935 melalui kongres perempuan organisasi-oraganisasi perempuan memutuskan untuk membentuk badan penyelidik tentang kedudukan perempuan dalam hukum Islam. Tujuan dari adanya badan penyelidik yaitu untuk mempersatukan oraganisasi perempuan yang tidak bertentangan dengan hukum agama. Badan penyelidik yang dibentuk diberi nama dengan Komite Penyelidik Hukum perkawinan yang diketuai oleh Maria Ulfa Santoso. ${ }^{15}$ Memasuki pasa pemerintahan jepang pergerakan organisasi perempuan semakin dibatasi pergerakanya. Hanya terdapat beberapa oraganisasi pemerintah yang diperbolehkan diantaranya yaitu Fujinkai. Sehingga pergerakan oraganisasi perempuan tidak mendapatkan perhatian pada masa ini.

Tahun 1945 Indonesia berada pada masa kemerdekaanya menjadikan bangkitnya pergerakan organisasi perempuan. ${ }^{16}$ Tahun 1950 merupakan masa

\footnotetext{
12 Cyndia Esti Sumiwi, “Perjanan Undang-Undang Perkawinan 1974-198,” Skripsi, Universitas Indonesia (2012), 37

${ }^{13}$ Cora Vreede-de Stuers, Sejarah Perempuan Indonesia, (Jakarta:Bambu, 2008),136

14 Rumadi, Wiwit Rizki fathurahman, Perempuan dalam Relasi Agama dan Negara, (Jakarta:Kompas Peremuan, 2010), 42

15 Maria Ulfa adalah mahasiswa Hukum Universitas leiden Belanda. Tahun 1939 menjadi kepala biro konsultasi perkawinan. Tahn 1946-1947 menjadi menteri sosial dalam kabinet Syahrir. Tahun 1955 menjadi ketua kongres wanita Indonesia. Ibid, 290

16 Hikmah Diniah, Gerwani Bukan PKI: Sebuah Gerakan Feminisme Terbesar di Indonesia, (Yogyakarta:Carasvati Book, 2007), 163
} 
kebangkitan organisasi perempuan yang ditandai dengan munculnya berbagai tuntutan dalam hukum perkawinan. Pada tahun 1950-1956 muncul organisasi perempuan yang bersifat progresif. Hal ini dikarenakan memiliki program kerja yang nyata dan diimplementasikan kepada masyarakat. Salah satu organisasi yang ada sejak awal kemerdekaan yaitu Persatuan Wanita republik Indonesia (PERWARI) yang dibentuk tahun $1945 .{ }^{17}$ Organisasi ini sudah aktif membela hakhak kaum perempuan dalam bidang politik, Perkawinan dan juga pekerjaan. Selain PERWARI oraganisasi Gerakan Wanita Isteri Sedar (GEWIS) yang pada perkembanganya berubah menjadi Gerakan Wanita Indoneisa. Kedua organisasi ini merupakan oraganisasi perempuan yang giat menyoroti permasalahan peremuan dalam keluarga. Mereka juga menuntut adanya undang-undang perkawinan yang baru. Hal ini terbukti ketika pemerintah menetapkan peraturan pemerintah Nomor 19 Tahun 1952 yang berlaku untuk seluruh Indonesia. ${ }^{18}$ GERWANI dan PERWARI menolak adanya peraturan yang melegalkan poligami yang dilakukan oleh pejabat sipil. Pada tanggal 17 Desember 1953 terjadi demonstrasi besar-besaran yang dilakukan oeh PERWARI dan didukung oraganisasi lain, semakin hari pergerakan Perwari semakin dibatasi. Pada tahun 1955 PERWARI menyampaikan pendapat kepada pemerintah dalam masalah poligami bagi pejabat-pejabat.

Saat ulang tahun yang ke 17 Perwari pada tangga 17 Desember 1962 membuat pernyataan yang isinya mendesak lembaga pemerintah supaya segera diundangkan Undang-Undang perkawinan tersebut dengan tujuan adanya kesejahteraan keluarga. ${ }^{19}$ Tuntutan ini terus dibawa oleh perwari hingga tahun 1965 dengan terus bergerak aktif dan dibantu oleh organisasi lain. Tahun 1966 Soekarno jatuh dan digantikan oleh Soeharto. Pada masa pemerintahanya Soeharto memperbaiki sistem yang kacau pada masa orde lama. Masa orde baru pergerakan oraganisasi perempuan dan yang bersifat agama diberi ruang leluasa. Pada tahun 1973 DPR menerima rancangan undang-undang perkawinan dari pemerintah. Dan melalui beberapa proses akhirnya disetujui RUU Perkawinan menjadi Undang-Undang Nomor 1 Tahun 1974 tentang perkawinan. Dengan disahkanya Undang-Undang Nomor 1 Tahun 1974 disusul dengan dibuatnya beberapa peraturan baru yaitu Peraturan Pemerintah (PP) Nomor 9 Tahun 1975 tentang pelaksanaan Undang-Undang Nomor 1 Tahun 1974. Kemudian disusul keluarnya Peraturan Menteri agama dan Menteri Dalam Negeri yang berisi tentang pelaksanaan Undang-Undang perkawinan tersebut. ${ }^{20}$ Isi dari Peraturan Menteri Agama yang dikeluarkan 19 Juli 1975 ada dua yaitu:

\footnotetext{
17 Cora Vreede-de Stuers, Sejarah Perempuan Indonesia, (Jakarta:Bambu, 2008), 176

18 Cora Vreede-de Stuers, Sejarah Perempuan Indonesia, (Jakarta:Bambu, 2008), 202

19 Yuni Setia Rahayu, "Konsistensi Perwari Dalam Membela Hak Peremuan: Tinjauan terhadap kerja perwari tahun 1945-1965”, TesisUniversitas Indonesia (2003), 66

20 Khoiruddin Nasution, Status Wanit di Asia Tenggara: Studi Terhadap Perundang-Undangan Perkawinan Muslim Kontemporer di Indonesia dan Malaysia, (Jakarta:INIS, 2002), 43
} 
a. Menag Nomor 3 Tahun 1975 tentang kewajiban pegawai pencatatan nikah dan tata kerja pengadilan agama dalam melaksanakan UU perkawinan bagi yang beragama islam.

b. Menag Nomor 4 Tahun 1975 tentang contoh-contoh akta nikah, cerai, talak dan rujuk.

Undang-Undang Nomor 1 Tahun 1974 meskipun sudah diundangkan sejak 2 Januari 2017 tetapi mulai berlaku efektif sejak 1 Oktober 1975. Hal ini dikarenakan untuk melaksanakan undang-undang terebut diperlukan langkahlangkah persiapan dan beberapa petunjuk pelaksanaan dari berbagai instansi terkait. Sehingga dierlukan waktu enam bulan lebih untuk dapat dilaksanakan. ${ }^{21}$

Isi dari Undang-Undang Nomor 1 Tahun 1974 tidak melarang adanya poligami, tetapi memperbolehkan dengan syarat yang memberatkan adanya suatu poligami. Dan yan terpenting dari adanya Undang-Undang Nomor 1 Tahun 1974 yaitu asas dari perkawinan di Indonesia yaitu monogami. ${ }^{22}$ Hak-hak dan kewajiban antara suami dan istri juga diatur sedemikian rupa sehingga tidak menjatuhkan kedudukan perempuan dalam perkawinan.

\section{PROSES PERUMUSAN RUUP NOMOR 1 TAHUN 1974}

Proses pertama pembentukan Undang-Undang perkawinan dilakukan pada 30 Agustus 1973 yaitu pemerintah memberikan keterangan yang disampaikan oleh menteri yang bersangkutan di hadapan sidang pleno DPR. Hal ini dilakukan setelah beberapa hari presiden menyampaikan surat dengan lampiran naskah RUU kepada pimpinan DPR. Pimpinan DPR lalu membagikan kepada anggotanya. Keterangan dari pemerintah pada saat itu diwakili oleh Menteri Kehakiman Oemar Senoadji, Menteri Agama Mukti Ali dan sampai selesai presiden diwakili oleh kedua menteri tersebut. ${ }^{23}$

Proses selanjutnya yaitu pidato dari anggota-angota DPR yang diwakili juru bicara dari masing-masing fraksi. Masing-masing fraksi mendapatkan waktu yang sama untuk menyampaikan pendapatnya masing-masing. Pada waktu itu terdapat empat fraksi menyatakan pendapat yaitu fraksi Persatuan Pembangnan, PDI, Karya dan ABRI. Pada tahapan ketiga yaitu rapat kerja antar komisi DPR dengan pemerintah yang wakili oleh menteri. Pada tahapan inilah RUU diolah dengan dialog-dialog antara pemerintah dan anggota DPR yang merupakan dialog antara pemerintah dengan fraksi DPR. Dialog antara pemerintah dan DPR dalam mengeluarkan pendapat harus sinkron, karena jika tidak maka akan memerlukan waktu berhari-hari untuk mendapatkan pendapat yang sama. Proses terkahir yaitu sidang pleno DPR untuk mengesahkan undang-undang tersebut. Setelah disepakati

${ }^{21}$ Khoiruddin Nasution, Hukum Keluarga (Perdata)Islam Indonesia, Yogyakarta: ACAdeMIA + TAZZAFA, 2010), 135

22 Pasal 1 ayat 1 UU No.1 tahun 1974

${ }^{23}$ Amak FZ, Proses Undang-Undang Perkawinan, (Bndung: al Ma'arif, 1976), 9 
maka selesailah sidang tersebut kemudian DPR memberikan naskah RUU kepada presiden untuk ditandatangani dan diundangkan. Dan setelah ditandatangani oleh sekertaris negara maka UU tersebut sah dan harus ditaati oleh seluruh masyarkat Indonesia. Tanggal 2 januari 1974 Presiden Soeharto akhirnya mengesahkan UU No.1 tahun 1974. ${ }^{24}$ Setelah pemerintah mengesahkan Undang-Undang ini maka pemerintah segera mengeluarkan PP Nomor 9 Tahun 1975 yang isinya mengenai pelaksanaan Undang-Undang Nomor 1 Tahun 1974 dan juga dikeluarkan Peraturan Menteri Agama pada juli 1975 No.3 dan No.4 yang berisikan kewajiban pegawai pencatat nikah dan tata kerja pengadilan agama, serta contoh-contoh akta nikah, cerai, talak dan rujuk.

\section{PRO DAN KONTRA PEMBAHASAN RANCANGAN UNDANG-UNDANG PERKAWINAN}

Proses pengesahan RUUP tidak berjalan dengan mudah, perbedaan pendapat dan masukan dari anggota-anggota DPR, elit politik, antar anggota masyarakat pun ikut memberikan pendapatnya. Tuntutan yang diberikan tidaklah sama dengan yang dilakukan pada tahun 1950-an yang menyatakan keberatan akan adanya poligami dan mengusung hak-hak perempuan dalam perkawinan supaya lebih diperhatikan. Pada Mei 1967 memang RUUP telah diajukan tetapi mendapat penolakan dari fraksi Khatolik. Alasan penolakanya dikarenakan tidak mau membahas suatu hal yang berhubungan dengan hukum agama. Meskipun perwakilan dari fraksi ini cukup sedikit yaitu 8 anggota dari 500 anggota DPR tetapi pendapat mereka membuat RUU pekawinan berhenti dibahas. ${ }^{25}$ Lalu pada 31 Juli 1973 pemerintah kembali mengajukan RUUP ke DPR. Tetapi sebelum rancangan tersebut dibahas sebagian dari materi RUU telah terekspos di media massa. ${ }^{26}$ Sehingga tuntutan yang ada justru soal agama, dimana pasal-pasal tersebut oleh fraksi Persatuan Pembangunan dianggap tidak sesuai dengan aturan agama. Beberapa pasal yang dianggap bertentangan dengan ajaran Islam yaitu:

1. Sahnya perkawinan yang tidak berdasakan agama Islam.

2. Anak angkat mempunyai kedudukan hukum yang sama dengan anak kandung,

3. Larangan adanya perkawinan karena adanya hubungan anak angkat atau bapak angkat,

4. Perbedaan agama bukanlah penghalang perkwainan. ${ }^{27}$

\footnotetext{
24 Ibid., 10

25 Cyndia Esti Sumiwi, “Perjanan Undang-Undang Perkawinan 1974-198," Skripsi, Universitas Indonesia (2012), 43

26 Aminudin, Kekuatan Islam dan Pergulatan kekuasaan di Indonesia Sebelum dan Sesudah Runtuhnya Rezim Soeharto, (Yogyakarta: Pustaka Pelajar, 1999), 100

27 Cyndia Esti Sumiwi, “Perjanan Undang-Undang Perkawinan 1974-198," Skripsi, Universitas Indonesia (2012), 44
} 
Fraksi Persatuan Pemangunan berpegang pada hasil musyawarah ulama NU yang dilakukan di jombang dimana setelah RUU masuk ke DPR mereka membahas pasal demi pasal untuk mencari aturan mana yang tidak sesuai dengan ajaran Islam. setelah didapatkan aturan yang tidak sesuai maka fraksi Persatuan Pembangunan membawanya ke PBNU jakarta dan dijadikan sebagai pedoman saat sidang di DPR. Sedangkan fraksi lain hanya melihat dari segi hak-hak perempuan yang menjadi topik oraganisasi-organisasi peremuan saat itu. Fraksi Persatuan yang sangat bersemangat merevisi RUU tersebut dari segi agama. Selain itu juga mendapat dukungan dari organisasi islam masyarakat seperti IPNU, PII, GMII dan para ulama. Mereka juga berdemo untuk mendukung pernyataan dari fraksi Persatuan itu. ${ }^{28}$ Isi dari tuntutan organisasi-oraganisasi islam ini yaitu:

1. Menolak RUUP yang diajukan pemerintah kepada DPR,

2. Menuntut pemerintah untuk mencabut kembali RUUP karena bertentangan dengan aturan agama islam,

3. Menyerukan kepada seluruh lapisan masyarakat termasuk sipil dan militer untuk tetap berpegang teguh pada akidah agama dengan konsekuen. ${ }^{29}$

Selain itu menurut fraksi Persatuan Pembangunan RUU ini tidak cocok karena banyak pasal-pasal yang diambil dari Burgerlijkwetbook (BW) dan HOCI. Setelah terjadi demonstrasi besar-besaran Menteri Agama Mukti Ali melakukan lobi politik dengan Fraksi tersebut dan juga para ulama. Dan selanjutnya pemerintah menunjuk Jendral Soemitro menjadi penanggungjawab masalah RUU perkawinan ini, yang sebelumnya menjadi tanggungjawab Ali Moertopo asisten pribadi Presiden. Soemitro bergerak cepat dengan melakukan berbagai pertemuan dengan kelompok Islam terutama dengan fraksi PPP. Hasil pertemuan dari Soemitro dengan kelompok Islam yaitu merombak RUU dari 73 pasal menjadi 66 Pasal dengan rumusan sebagai berikut:

1. Hukum Islam dalam perkawinan tidak akan dikurangi ataupun dirubah

2. Sebagai konsensus nomor satu, alat-alat pelaksana tidak akan dikurangi ataupun dirubah

3. Hal-hal yang bertentangan dengan hukum islam dan tidak sesuai dalam Undang-Undang perkawinan akan dihilangkan

4. Pasal 2 ayat 1 disetujui dengan rumusan "perkawinan adalah sah apabila dilakukan menurut hukum masing-masing agamanya dan kepercayaan itu" dan ayat 2 "Tiap-tiap perkawinan dicatat demi kepentingan administrasi negara"

\footnotetext{
${ }^{28}$ Ahmad Rifai dkk, Perjalanan Undang-Undang Perkawian Atas Pendapat Hingga Pertentangan dari Masyarakat dan DPR Tahun 1973-1974, (Semarang: UNES, 2015), 6

${ }^{29}$ Umaidi Radi, Strategi PPP 1973-1982 Suatu Studi Tentang kekuasaan Politik Islam di Tingkat Nasional, (Jakarta: Integrita Press, 1984), 122-123
} 
5. Perkawinan dan perceraian serta poligami perlu diusahakan untuk mencegah kesewenang-wenangan.

Dengan adanya pertemuan tersebut semua pasal yang dianggap bertentangan dengan hukum islam dirubah sehingga tidak bertentangan lagi. Sehingga setelah terjadinya kesepakatan ini RUU perkawinan bisa dilanjutkan dibahas dengan adanya persetujuan semua fraksi. Padahal sebelum adanya pertemuan ini fraksi Persatuan Pembangunan tidak mau melanjutkan pembahasan pada sidang ketiga. Hal ini dilakukan sebagai aksi protes atas tidak setuju isi dari RUUP. Pada sidang ketiga berbagai permasalahan juga terjadi dalam setiap dialog. Bahkan berulangkali sidang diskors, hal ini disebabkan pembicaraan yang sulit dari pasal-pasal RUU perkawinan itu sendiri. Pembahasan paling lama yaitu pasal 1 sampai sebelas hari. ${ }^{30}$ Pembahasan pada pasal 1 ini berjalan cukup lama karena adanya perdebatan dari raksi Demokrasi Indonesia dengan fraksi Persatuan Pembangunan. Untuk menengahi perdebatan tersebut akhirnya ketua sidang mengembalikan pada rumusan semula yaitu rumusan pemerintah. Setelah selesai pembahasan pasal 1 dilanjutkan pembahasan pasal 2 yaitu hasil dari pertemuan Soemitro dengan golongan muslim. Pada pembahasan ini fraksi Demokrasi Indonesia (PDI) menyampaika gugatan bahwa rumusan tersebut bisa disimpulkan bahwa hukum negara harus dimasukan pada hukum agama. Ia mengusulkan untuk menambahkan kata-kata "dan atau menurut perundang-undangan yang berlaku"sesudah kata keperayaan. Tetapi rumusan pertamalah yang akhirnya diterima oleh panitia kerja.

\section{TUJUAN DIBUATNYA UNDANG-UNDANG NOMOR 1 TAHUN 1974}

Undang-Undang Nomor 1 Tahun 1974 Tentang Perkawinan merupakan Undang-Undang perkawinan pertama di Indonesia dengan asas monogami. Aturan ini ditetapkan pada 2 Januari 1974. Undang-undang ini dinilai sebagai usaha keberhasilan organisasi perempuan di Indonesia untuk menjunjung dan melindungi hak-hak perempuan dalam sebuah perkawinan. Dengan adanya perbedaan sistem perkawinan yang digunakan sejak sebelum Indonesia merdeka, oraganisasi perempuan berusaha keras untuk mengusulkan suatu Undang-Undang perkawinan yang dapat dijadikan tolok ukur aturan perkawinan seluruh masyarakat Indonesia. ${ }^{31}$ Dengan adanya Undang-Undang perkawinan banyak hal yang dapat berubah kedepanya, diantaranya:

a) kedudukan perempuan dalam perkawinan semakin terjamin hak-haknya dalam berumah tangga. Begitu juga dalam kasus poligami seorang suami tidak lagi bisa sewenang-wenang melakukan poligami tanpa persetujuan

\footnotetext{
30 Cyndia Esti Sumiwi, “Perjanan Undang-Undang Perkawinan 1974-198," Skripsi, Universitas Indonesia (2012), 45

${ }^{31}$ June S Katz \& Roald S.Katz, The new Indonesian Marriage Law: A Mirror of Indonesia's Politicl, Cultural and Legal System, http://www.jstor.org/stable/839240, 1975, 21 September 2019.
} 
dari istri terdahulu. Kerja keras para perempuan sejak 1950 untuk menjunjung hak-hak perempuan dapat terlaksana dengan disahkanya undang-undang perkawinan ini.

b) PNS tidak lagi mendapatkan tunjangan untuk istri yang kedua maupun seterusnya. Begitu juga saat akan berpoligami PNS tidak bisa semudah zaman dulu.

c) Dengan disahkanya undang-undang perkawinan membuat susahnya seseorang yang akan berpoligami. Sehingga justru muncul masalah-masalah baru seperti nikah sirri atau bahkan pernikahan yang dilarang menurut agama.

Undang-Undang Nomor 1 Tahun 1974 tentang perkawinan tidak begitu saja dibuat oleh pemerintah. Dengan melihat alur sejarah dari sebelum kemerdekaan sampai pada disahkanya undang-undang perkawinan ini alasan yang paling terasa yaitu datang dari dorongan organisasi-oraganisasi perempuan yag menginginkan kesetaraan hak-hak antara kaum perempuan dan laki-laki dalam perkawinan. Selain itu sejak zaman sebelum kemerdekaan poligami jelas banyak dilakukan, bahkan didalam hukum Islam juga diperbolehkan. Para aktivis perempuan berusaha untuk memerangi adanya poligami. Dengan adanya undang-undang perkawinan maka asas perkawinan yaitu monogami sesuai dengan pasal 3 ayat 1 Undang-Undang Nomor 1 Tahun 1974. ${ }^{32}$ Dalam menangani permasalahan poligami undang-undang perkawinan tidak melarang begitu saja, tetapi seorang suami diperbolehkan melakukan poligami dengan berbagai syarat yang harus dilaksanakan. Seorang suami yang hendak berpoligami harus mendapatkan izin dari pengadilan agama. Jika tidak memenuhi syarat sesuai dalam undang-undang maka suami tidak diperbolehkan untuk berpoligami. Hal ini sesuai dengan pasal 3,4 dan 5 Undang-Undang Nomor 1 Tahun 1974.

Pengesahan Undang-Undang perkawinan ini dilakukan dengan tujuan adanya kodifikasi dan unifikasi hukum perkawinan yang berlaku untuk seluruh masyarakat Indonesia. Dengan adanya kodifikasi dan unifikasi tentu akan mempermudah masyarakat dan juga praktisi hukum dalam menerapkan hukum. Mengingat pada masa sebelum disahkanya Undang-Undang perkawinan hukum yang digunakan dalam hal perkawinan sangat beragam. Apalagi dikalangan umat Islam yang merujuk kitab-kitab fikih ulama terdahulu. Tentu dalam memahami pun bisa berbeda-beda. Hal ini membuat banyaknya celah permasalahan yang akan terjadi di masyarakat.

Secara umum tujuan pembaruan hukum keluarga Islam dapat dikelompokan mejadi tiga yaitu: 33

\footnotetext{
32 Pada azasnya dalam suatu perkawinan seorang pria hanya boleh menikahi seorang istri. Seorang wanita hanya boleh mempunyai seorang suami.

33 Khoiruddin Nasution, Hukum Keluarga (Perdata)Islam Indonesia, Yogyakarta: ACAdeMIA + TAZZAFA, 2010), 40
} 
1. Unifikasi hukum perkwinan

2. Peningkatan status wanita

3. Respon terhadap pembaruan hukum dan menyesuaikan perkembangan zaman

Pertama adanya unifikasi hukum yang diberlakukan untuk seluruh masyarakat Indonesia. Dengan adanya unifikasi hukum perkawinan dapat membantu para hakim dalam menyelesaikan perkara dan meminimalisir adanya perbedaan sumber hukum dan putusan dalam kasus yang sama. Kedua peningkatan status wanita yaitu dapat dilihat dari tuntutan organisasi perempuan yang menginginkan adanya hukum perkawinan yang baru dan lebih memperhatikan kedudukan perempuan dalam keluarga. Sehingga tidak terjadi lagi kawin paksa, perkawinan anak maupun poligami secara bebas. Ketiga merespon perkembangan zaman karena konsep fikih yang digunakan sebelum adanya Undang-Undang perkawinan dapat dikatakan kurang mampu menjawab permasalahan keluarga. Sehingga dengan adanya Undang-Undang perkawinan diharapkan dapat menjawab dan mengcover permasalahan-permasalahan dalam keluarga.

Adapun cakupan Undang-Undang dalam asek perkwinan dan perceraian yaitu Undang-Undang Nomor 1 Tahun 1974 dengan 13 bab 67 pasal susunan seagai berikut: ${ }^{34}$

Bab I : Dasar Perkawinan (pasal 1-5)

Bab II: Syarat-Syarat Perkawinan (Pasal 6-12)

Bab III:Pencegahan Perkawinan (Pasal 13-21)

Bab IV :Batalnya Perkawinan (Pasal 22-28)

Bab V: Perjanjian Perkawinan(Pasal 29)

Bab VI : Hak dan Kewajiban Suami Istri (Pasal 30-34)

Bab VII:Harta Benda Dalam Perkawinan(Pasal 35-37)

Bab VIII: Putusnya perkawinan Serta Akibatnya(Pasal 38-41)

Bab IX : Kedudukan Anak (Pasal 42-44)

Bab X: Hak dan Kewajiban Antara Orang Tua dan Anak(Pasal 45-49)

Bab XI: Perwalian (Pasal 50-54)

Bab XII: Ketentuan-ketentuan Umum yan Terdiri dari empat bagian

Bagian Pertama: Pembuktian Asal-Usul Anak (Pasal 55)

Bagian Kedua: Perkawina di Luar Indonesia (Pasal 56)

Bagian Ketiga : Perkawinan Campuran (pasal 57-62)

Bagian keempat: pengadilan (pasal 63)

Bab XIII: Ketentuan Peralihan (pasal 64-65)

Bab XIV: Ketentuan Penutup (pasal 66-67)

34 Khoiruddin Nasution, Hukum Keluarga (Perdata)Islam Indonesia, Yogyakarta: ACAdeMIA + TAZZAFA, 2010), 18 
Setelah disahkanya undang-undang perkawinan tidak begitu saja berjalan mulus. Setelah disahkanya undang-undang perkawinan tahun 1974 juga dikeluarkan Peraturan Pemerintah Nomor 10 Tahun 1983 tentang izin pernikahan dan perceraian bagi PNS. ${ }^{35}$ Hal yang mendorong dikeluarkanya Perturan Pemerintah tersebut adalah tuntutan dari para anggota Dharma wanita yang resah dengan perbuatan suami yang berpoligami secara diam-diam maupun perceraian sewenang-wenang. Pada intinya Peraturan Pemerintah ini mengatur apabila ingin melakukan perkawinan yang kedua/ketiga/keempat harus mendapat izin dari atasan dan secara tertulis. Jika tidak mengikuti peraturan yang ada maka akan diberikan sanksi. Dari uraian diatas dapat dikataan membuat sebuah undangundang memerlukan pemikiran dan keseriusan, terlebih lagi undang-undang perkawinan merupakan aturan yang krusial bagi perempuan Indonesia.

\section{PENUTUP}

Hukum perkawinan yang berlaku sebelum dibentuknya perundangundangan perkawinan diantaranya, bagi orang-orang Indonesia asli yang bergama islam berlaku hukum agama yang telah diresepsi dengan hukum adat. Bagi orangorang Indonesia lainya yang beragama selain islam berlaku hukum adat. Orangorang Indonesia asli yang beragama Kristen berlaku Huwelijks Ordonantie christen Indoneia (HOCI) dalam Staatsblad 1933 No.74. Orang-orang timur asing, Eropa dan orang Indonesia keturunan Cina berlaku hukum perdata Burgerlijk Wetboek.

Isu- isu yang terjadi dalam perkawinan sebelum adanya undang-undang tentang perkawinan diantaranya, adanya praktek poligami yang semena-mena, penggunaan sumber hukum perkawinan yang masih berbeda-beda, adanya perkawinan anak, dan perkawinan secara paksa. Kesemuanya ini merupakan permasalahan yang terjadi di masyarakat yang menjadi alasan dibentuknya Undang-Undang Nomor 1 Tahun 1974 Tentang Perkawinan.

Selanjutnya dalam sejarah perjalanan dibentuknya perundang-undangan perkawinan tidak lepas dari campurtangan oraganisasi perempuan pada saat itu. Oraganisasi tersebut diantaranya, GERWANI dan PERWARI. Berkat perjuangan organisasi perempuan dan juga masyarakat akhirnya tangga 31 Juli 1973 pemerintah mengajukan RUU perkawinan ke DPR. Perumusan dan pembahasan perundang-undangan perkawinan berjalan kurang lebih selama tujuh bulan. Kemudian pada tanggal 2 Januari 1974 presiden mengesahkan Undang-Undang Nomor 1 Tahun 1974 Tentang Perkawinan. Tujuan adanya perundang-undangan perkawinan diantaranya yaitu unifikasi hukum perkawinan, peningkatan status wanita, respon terhadap pembaruan hukum dan menyesuaikan perkembangan zaman. Dengan adanya aturan tentang perkawinan diharapkan praktik tentang nikah anak, poligami, dan hal-hal yang merendahkan posisi peremuan dalam

\footnotetext{
${ }^{35}$ Khoiruddin Nasution, Hukum Keluarga,.., 138
} 
perkawinan dapat teratasi. Salah satu contohnya dengan adanya pasal tentang poligami maka suami tidak dengan mudah melakukan poligami secara bebas dan mudah, karena dalam undang-undang perkawinan terdapat syarat-syarat yang harus dipenuhi suami yang akan dipoligami dan harus melalui izin dari lembaga pengadilan, dengan begitu hak-hak perempuan dalam keluarga lebih terlindungi.

\section{DAFTAR PUSTAKA}

Aminudin. Kekuatan Islam dan Pergulatan kekuasaan di Indonesia Sebelum dan Sesudah Runtuhnya Rezim Soehart., Yogyakarta: Pustaka Pelajar. 1999.

Ahmad Rifai dkk. Perjalanan Undang-Undang Perkawian Atas Pendapat Hingga Pertentangan dari Masyarakat dan DPR Tahun 1973-1974. Semarang: UNES. 2015.

Amak FZ. Proses Undang-Undang Perkawinan. Bandung: al Ma'arif. 1976.

Diniah , Hikmah. Gerwani Bukan PKI: Sebuah Gerakan Feminisme Terbesar di Indonesia. Yogyakarta:Carasvati Book. 2007.

June S Katz \& Roald S.Katz. The new Indonesian Marriage Law: A Mirror of Indonesia's Political, Cultural and Legal System, http://www.jstor.org/stable/839240, 1975.

Nasution, Khoiruddin. Status Wanit di Asia Tenggara: Studi Terhadap PerundangUndangan Perkawinan Muslim Kontemporer di Indonesia dan Malaysi. Jakarta:INIS. 2002.

Rumadi, Wiwit Rizki fathurahman. Perempuan dalam Relasi Agama dan Negara. Jakarta:Kompas Peremuan. 2010.

Radi, Umaidi. Strategi PPP 1973-1982 Suatu Studi Tentang kekuasaan Politik Islam di Tingkat Nasional. Jakarta: Integrita Press. 1984.

Rahayu, Yuni Setia. Konsistensi Perwari Dalam Membela Hak Peremuan: Tinjauan terhadap kerja perwari tahun 1945-1965, pascasarjana UI. 2003.

Supriadi, Wila Chandrawila. Hukum Perkawinan Indonesia dan Belanda, Bandung: Bandar Maju. 2002.

Sumiwi , Cyndia Esti. Perjanan Undang-Undang Perkawinan 1974-198. Depok: UI. 2012.

Stuers , Cora Vreede-de. Sejarah Perempuan Indonesia. Jakarta:Bambu. 2008.

Wasman dan Wardah Nuroniyah. Hukum Perkawinan Islam di Indonesia. Yogykarta: Teras. 2000.

Pasal 1 ayat 1 Undang-Undang Nomor 1 tahun 1974

Pasal 29 ayat 2 UUD 1945 